\title{
The effects of different irrigation agents on root canal dentine micro-hardness and surface roughness
}

\author{
Faruk Öztekin ${ }^{1}$, Özkan Adıgüzel2 \\ ${ }^{1}$ Fırat University, Faculty of Dentistry, Department of Endodontics, Elazığ, Turkey. \\ ${ }^{2}$ Dicle University, Faculty of Dentistry, Department of Endodontics, Diyarbakır, Turkey.
}

\section{Correspondence:}

\section{Dr. Faruk ÖZTEKiN}

Firat University, Faculty of Dentistry,

Department of Endodontics, Elazı̆̆,

Turkey.

E-mail:foztekin@firat.edu.tr

Received: 16 October 2018

Accepted: 22 February 2019

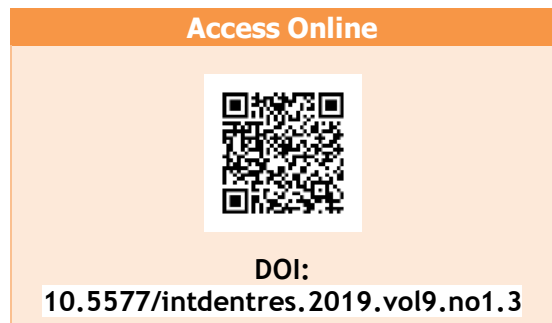

\section{Introduction}

The aim of a root canal treatment is to disinfect the root canal sufficiently to prevent further infection (1). Thus, successful root canal treatments rely on adequate canal preparations, effective irrigation, and complete three-dimensional (3D) canal filling.

Irrigation is one of the most important procedures of root canal treatment since it is at this stage that pulp tissues, residues, smear layers, microorganisms, and toxic products are removed from the root canal (2). Therefore, the correct irrigation agents should be used and applied properly (3). Because the complicated anatomy of the root canal prevents mechanical cleaning from fully removing the above items, irrigation is required (2).

Sodium hypochlorite $(\mathrm{NaOCl})$, chlorhexidine $(\mathrm{CHX})$, and ethylenediaminetetraacetic acid (EDTA) are common irrigation agents, with $\mathrm{NaOCl}$ being the 
primary endodontic agent. However, $\mathrm{NaOCl}$ has no effect on inorganic structures (1). $\mathrm{NaOCl}$ removes the organic portion of the smear layer and exhibits broadspectrum antimicrobial activities against viruses, bacteriophage, spores, and fungi (4).

$\mathrm{CHX}$ also has broad-spectrum antimicrobial activities that are bacteriostatic at low concentrations and bactericidal at high concentrations (5). Reports suggest that $2 \% \mathrm{CHX}$ prevents damage to root canal dentine during disinfection (6), and it bonds to hard tissues to exhibit extended antimicrobial activity (7). Weak $\mathrm{CHX}$ solutions (0.1-0.2\% concentrations) are often used as mouthwashes; however, more potent solutions $(0.2-2 \%)$ are required for root canal irrigations (6).

QMix (Dentsply Tulsa Dental Specialties, Tulsa, OK, USA) is a new root canal irrigant formulated for root canal disinfection and the removal of the smear layer (8). QMix is a combination of the antibacterial agent bisbiguanide, the chelator poliaminocarboxylic acid, deionized water, and sulphactan (9). According to the manufacturer, QMix contains EDTA, CHX, and a surface-active agent (8). The detergents in QMix reduce surface tension and increase the surface wettability (10). Previous reports have suggested that Qmix be used as a post-washing solution; however, it may also disinfect root canals since this agent has been shown to open dentine tubules (7). QMix is used with chlorhexidine and $\mathrm{NaOCl}$ to prevent the formation of precipitates (11).

Tooth tissues or dental materials are often evaluated by their surface hardness, which is affected by multiple chemical and physical factors. Hardness (rigidity) refers to the "resistance of a material against deformation", including expanding, reshaping, and resistance to pulling and pressing. Surface hardness is also used to evaluate a material's resistance to abrasion (12). Multiple methods are available to assess surface roughness, including scanning electron microscopy (SEM) and surface profile analyses. Recently, 3D topographic images have also been obtained using atomic weight microscopy to evaluate surface roughness (13). Additionally, a diamond scanner bit on a profilometer machine also explores surface roughness (14) under multiple parameters, including the $\mathrm{Ra}, \mathrm{Rpm}, \mathrm{Rz}$ and $\mathrm{Rz}$ :Rpm ratio (15).

Although the relative softening of dentine caused by chemical irrigants provides clinical benefits, including rapid preparation and opening of obstructed canals, such changes do not affect the adhesion or 3D filling of the channel-filler materials used to treat dentine (16). However, the changes caused by the irrigation solution reduce the resistance of dentine to stress, affects the removal of bacteria, and influences the ability of the filling materials to bind to the canal wall $(17,18)$.

\section{Materials and Methods}

A total of 60 non-carious maxillary incisors and canines were used in this study. All teeth were extracted for various periodontal reasons from patients aged 35-50. When extracting teeth, similarly-sized roots and teeth that had not previously undergone restorative or endodontic treatments were selected. Tooth radiographs were used to preferentially identify and select teeth with calcifications along the root canal, or those containing approximately the same width of pulp. Tooth crowns were separated from their roots at the enamel-cement boundary using a highspeed drill and stored in distilled water at room temperature $\left(25^{\circ} \mathrm{C}\right)$.

Roots that were separated from their crowns were longitudinally divided with a diamond saw (Horico, Berlin, Germany) using distilled-water cooling. Samples were embedded horizontally in polymerized acrylic blocks, ensuring that the root dentine remained open (Fig. 1). A total of 10 roots were embedded in each block. The dentine surfaces were sanded using sandpaper (silicon carbide abrasive paper; 500, 800, 1000 , and 1200 grit) and distilled water, and polished using a 0.1-micron alumina suspension (Ultra-sol; Eminess Tec Inc, Monroe, NC, U.S.) and a felt disc.
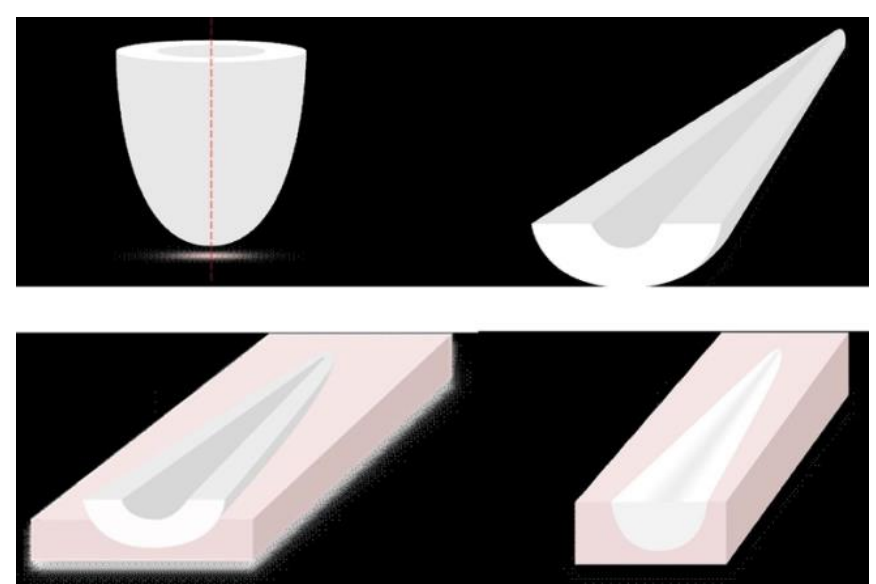

Figure 1. Three-dimensional image of the samples prepared prior to the study.

Samples were divided into A and B groups containing six acrylic blocks each. Each group was then further subdivided into $A 1, A 2, A 3$, and B1, B2, B3 subgroups (Fig. 2 and Table 1).

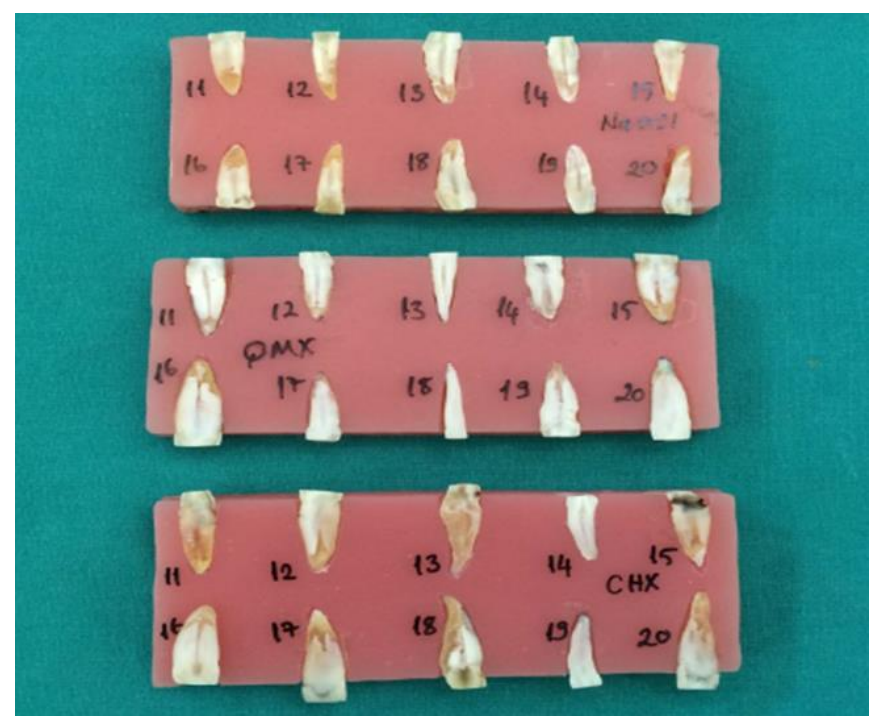

Figure 2. Prepared samples 
Group A was used to test the surface roughness of the dentine. Initial surface roughness measurements (Mitutoyo SJ 310 Kanagawa, Japan) were obtained according to the following: five measurements from each tooth were obtained over a length of $0.25 \mathrm{~mm}$ for each measurement. The probe speed was $0.5 \mathrm{~mm} / \mathrm{sec}$, and a total of $1.25 \mathrm{~mm}$ was measured. The arithmetic mean of all five values was then taken as the initial surface roughness value (mean $\mathrm{Ra}$ ). $5 \% \mathrm{NaOCl}$ was applied for $15 \mathrm{~min}$ to the $\mathrm{A} 1$ subgroup samples, the QMix 2-in-1 solution was applied for 15 min to the A2 subgroup samples, and $2 \%$ CHX was applied for $15 \mathrm{~min}$ to the $A 3$ subgroup samples. Following the $15-\mathrm{min}$ treatment, the samples were washed with distilled water and dried. Five additional measurements were then obtained for each sample, and the arithmetic mean was taken as the post-process surface roughness value.
Group B samples were used to evaluate surface micro-hardness using the Vickers hardness test. Prior to the irrigation process, the average micro-hardness in each block was defined as the average of three measurements from the apical triplet, middle triplet, and cervical triplet of the roots using a Vickers hardness-testing device (Shimadzu HMV-2, Japan) with a $300 \mathrm{gr}$ force for 20 seconds. $5 \% \mathrm{NaOCl}$ was applied for $15 \mathrm{~min}$ to the A1 subgroup samples, the QMix 2-in-1 solution was applied for 15 min to the $A 2$ subgroup samples, and $2 \% \mathrm{CHX}$ was applied for $15 \mathrm{~min}$ to the $\mathrm{A} 3$ subgroup samples. Following the 15 -min treatment, the samples were washed with distilled water and dried. Three surface micro-hardness measurements were again obtained from each sample and the averages were recorded. The pre- and post-irrigation surface micro-hardness values were evaluated using the Annova-Tukey test.

Table 1. Classification of teeth used in this study.

\begin{tabular}{lcccc} 
Group & $\begin{array}{c}\text { Group A } \\
\text { (Surface } \\
\text { Roughness) }\end{array}$ & Number of Teeth & $\begin{array}{c}\text { Group B } \\
\text { (Micro-hardness) }\end{array}$ & Number of Teeth \\
\hline $5 \% \mathrm{NaOCl}$ & $\mathrm{A} 1$ & 20 & B1 & 20 \\
\hline QMIX & $\mathrm{A} 2$ & 20 & B2 & 20 \\
\hline $2 \% \mathrm{CHX}$ & $\mathrm{A} 3$ & 20 & B3 & 20 \\
\hline
\end{tabular}

\section{Statistical Analysis}

Data were analyzed using SPSS software (Statistical Package for Social Sciences, version 21.0) SPSS Inc., Chicago, II., USA). In the statistical analysis of the groups ANOVA analysis of variance and Tukey test was applied and a significant difference in all groups in statistically was observed $(p<0.05)$. The results are given with 95\% confidence intervals.

\section{Results}

Statistical significances and standard deviations for the assessments of root dentine microhardness and surface roughness are provided in Tables 2 and 3.
Micro-hardness was not significantly different between samples treated with QMix or $5 \% \mathrm{NaOCl}$ ( $p>0.05)$. Treatment with these agents caused similar reductions in micro-hardness. A significant difference was observed, however, between the QMix- and 2\% $\mathrm{CHX}$-treated groups, and between the $5 \% \mathrm{NaOCl}$ and QMix-treated groups $(\mathrm{p}<0.05)$. Treatment with $2 \% \mathrm{CHX}$ reduced the micro-hardness to a lesser extent than the other irrigation agents.

A significant difference in surface roughness was observed between the QMix and 2\% CHX treatments, and between the $5 \% \mathrm{NaOCl}$ and QMix treatments $(p<0.05)$. The QMix treatment increased the surface roughness more substantially than did treatments with the other agents. Based on binary comparisons, no difference in surface roughness was observed between treatments with $5 \% \mathrm{NaOCl}$ or $2 \%$ $\mathrm{CHX}$. 
Table 2. Assessments of root micro-hardness.

\begin{tabular}{|c|c|c|}
\hline Group & $\mathbf{N}$ & $\begin{array}{l}\text { Vickers Micro-Hardness Values } \\
\text { (Mean } \pm \text { SD) }\end{array}$ \\
\hline \multicolumn{3}{|c|}{ Pre-Irrigation } \\
\hline QMix 2-in-1 & 20 & $55.50 \pm 10.25$ \\
\hline $5 \% \mathrm{NaOCl}$ & 20 & $51.56 \pm 10.88$ \\
\hline $2 \% \mathrm{CHX}$ & 20 & $55.26 \pm 5.35$ \\
\hline \multicolumn{3}{|c|}{ Post-Irrigation } \\
\hline QMix 2-in-1 & 20 & $38.16 \pm 4.44$ \\
\hline $5 \% \mathrm{NaOCl}$ & 20 & $39.07 \pm 11.13$ \\
\hline $2 \% \mathrm{CHX}$ & 20 & $53.54 \pm 5.47$ \\
\hline
\end{tabular}

Table 3. Assessments of root dentine surface roughness.

\begin{tabular}{|lcc|}
\hline Group & N & $\begin{array}{c}\text { Roughness Values } \\
\text { (Mean } \pm \text { SD) }\end{array}$ \\
\hline QMix 2-in-1 & Pre-Irrigation & \\
\hline $5 \% \mathrm{NaOCl}$ & 20 & $0.24 \pm 0.09$ \\
\hline $2 \% \mathrm{CHX}$ & 20 & $0.20 \pm 0.05$ \\
& 20 & $0.18 \pm 0.05$ \\
\hline OMix 2-in-1 & Post-Irrigation & \\
\hline $5 \% \mathrm{NaOCl}$ & 20 & $0.47 \pm 0.11$ \\
\hline $2 \% \mathrm{CHX}$ & 20 & $0.22 \pm 0.05$ \\
\hline
\end{tabular}

\section{Discussion}

The irrigation procedure, which is one of the most important steps in root canal treatment, affects the root dentine micro-hardness and surface roughness parameters. All of the irrigation agents used in this study reduced dentine micro-hardness and increased surface roughness. While the QMix irrigation agent and $5 \% \mathrm{NaOCl}$ reduced dentine micro-hardness equally, $2 \%$ $\mathrm{CHX}$ caused less of a decrease than the other agents. The QMix agent also caused a significant increase in surface roughness, whereas $5 \% \mathrm{NaOCl}$ and $2 \% \mathrm{CHX}$ caused equal increases, albeit less than that observed with QMix.

The Knoop pit micro-hardness (19) and the Vickers micro-hardness tests (20) have been used previously with the Vickers micro-hardness test, and have been shown to be appropriate for assessing dental tissues treated with chemicals $(20,21)$. Although some studies have used the Knoop hardness test to evaluate surface changes of hard dental tissues, the Vickers micro-hardness test was considered more suitable for the current study (19).
Micro-hardness can provide information about mineral loss or gain in teeth (22) since the hardness of dentine depends on its physical properties and structure. The number and diameter of dentine tubules play an important role in the efficacy of an irrigation agent $(23,24)$. The hardness of the tissues nearest the pulp is lowest and is similar to dentine (25). In fact, Pashley et al. reported that dentine micro-hardness became lower as it progressed from the surface to the deep zone (19). Additionally, the amount of hydroxyapatite and the intertubular agent's mineral content are important factors in evaluating the hardness of dentine (26).

The application times of irrigants also influence tooth strength and structure (27). Studies have shown that a $15-\mathrm{min}$ treatment of $\mathrm{NaOCl}$ of varying concentrations or a 10 -min application of $6 \% \mathrm{NaOCl}$ were sufficient to reduce dentine micro-hardness (28, 29, 30). Similarly, another study showed that dentine micro-hardness varied between treatments of $2.5 \%$ and $6 \% \mathrm{NaOCl}$ for $5-20 \mathrm{~min}$, with reductions being most pronounced upon treatment with $6 \% \mathrm{NaOCl}$. The same study also showed that the 5-min application caused the same change in dentine micro-hardness as the extended treatments (30). 
Studies of $\mathrm{CHX}$ revealed that a 5-min treatment of the distal root canal dentine of the lower third molars with a $2 \% \mathrm{CHX} / \mathrm{CHX}$ Plus surface modifier solution caused no changes in micro-hardness. Similar studies have also reported that irrigation agents supplemented with surface modifiers failed to alter dentine micro-hardness (31). Additionally, Ari et al. reported that lower incisors treated for 15 min with $0.2 \% \mathrm{CHX}$ did not experience alterations to dentine hardness (28), and the adhesive binding strength of teeth treated with $\mathrm{CHX}$ solution was also higher than teeth treated with other solutions (32). However, no studies have assessed the combined impact of $2 \% \mathrm{CHX}$ on root canal dentine micro-hardness and surface roughness (29).

Arande-Garcia et al. evaluated the reducing effects of $17 \%$ EDTA, BioPure MTAD, SmearClear, and QMix irrigation solutions and found no differences (33). However, the current study found a significant reduction in dentine micro-hardness upon treatment with EDTA, CHX, or detergents containing irrigation agents.

QMix has been shown to increase the binding strength of the root canal filling material (34), which could be explained by the fact that this solution contains EDTA and CHX. QMix also significantly reduced the amount of bacteria on teeth; however, it was not as effective as $\mathrm{NaOCl}$. Treatments with QMix for as little as $1 \mathrm{~min}$ were sufficient to decrease bacterial counts, but extended incubations were required for bactericidal activity (35).

The solubility of organic matter in $\mathrm{NaOCl}$ solutions could explain the observed increase in surface roughness (36). Notably, Ari et al. reported a significant increase in surface roughness upon treatment with $\mathrm{NaOCl}(28)$ that was also supported by assessments using atomic force microscopy (37).

Treatment with $\mathrm{NaOCl}(0.5 \%, 1 \%, 2.25 \%)$ significantly decreased the amino-phosphate ratio in dentine in a dose-dependent manner. However, the treatment time did not affect the amino-phosphate ratio as treatments of $0.5 \% \mathrm{NaOCl}$ for 1,5 , or $10 \mathrm{~min}$ caused the same changes. Thus, it is possible to avoid changes in surface roughness caused by the dentine deproteinisation while obtaining high antibacterial activities over extended applications (38).

The softening effects of chemical irrigants on the dentine wall provide a clinical benefit during the preparation of small root canals (39). Surface roughness can also provide clinical benefits by increasing the micromechanical bond strength of the adhesive materials; however, rough surfaces also lead to plaque formation by encouraging bacterial adhesion (40). Thus, root canal dentine permeability and roughness positively influence the adhesion of canal fillers on the dentine surface $(41,42)$. However, an over-expansion of dentine may cause gaps that result in the diffusion of the filler onto the dentine surface (43).

The abrasiveness of irrigation solutions may cause changes to the dentine surface that could affect bacterial penetration or increased apical leakage (33). Therefore, further studies are required to determine the relationship between the optimum surface roughness, root canal strength, and channel-filler binding.

\section{Conclusions}

According to the results of microhardness it is observed that $5 \% \mathrm{NaOCl}$ and QMix combination of both irrigation agents reduce the level of micro hardness of the dentine equal and more than $\mathrm{CHX} 2 \%$ irrigation agent.

According to the surface roughness results QMix combination of both irrigation agent is caused a further increase in the dentine surface roughness than others. $5 \% \mathrm{NaOCl}$ and $2 \% \mathrm{CHX}$ agents has been the caused equal and less increase on the surface roughness.

Ethical Approval: Ethics committee approval was received for this study from Dicle University.

Peer-review: Externally peer-reviewed.

Author Contributions: Conception - F.Ö., Ö.A.; Design - F.Ö., Ö.A.; Supervision -Ö.A.; Materials - F.Ö., Data Collection and/or Processing - F.Ö., Ö.A.; Analysis and/or Interpretation - F.Ö., Literature Review - F.Ö., WriterF.Ö., Critical Review-Ö.A.

Conflict of Interest: No conflict of interest was declared by the authors.

Financial Disclosure: This work was supported by Research Fund of the Dicle University. Project Number: Diș.15.014

\section{References}

1. Zehnder M. Root canal irrigants. J Endod 2006;32:389-98. (Crossref)

2. Gu LS, Kim JR, Ling J, Choi KK, Pashley DH, Tay FR. Review of contemporary irrigant agitation techniques and devices. J Endod 2009;35(6):791-804. (Crossref)

3. de Gregorio C, Estevez R, Cisneros R, et al. Efficacy of different irrigation and activation systems on the penetration of sodium hypochlorite into simulated lateral canals and up to working length: an in vitro study. J Endod 2010;36:1216-21. (Crossref)

4. Çalıskan MK. Endodontide tanı ve tedaviler. Nobel Tıp Kitapevleri, İstanbul; s.243, 2006.

5. Gomes BP, Souza SF, Ferraz CC, et al. Effectiveness of $2 \%$ chlorhexidine gel and calcium hydroxide against Enterococcus faecalis in bovine root dentine in vitro. Int Endod J 2003;36:267-75. (Crossref)

6. Zamany A, Safavi K, Spangberg LS. The effect of chlorhexidine as an endodontic disinfectant. Oral Surg Oral Med Oral Pathol Oral Radiol Endod 2003;96:578-81. (Crossref)

7. Stojicic S, Shen Y, Qian W, et al. Antibacterial and smear layer removal ability of a novel irrigant, QMix. Int Endod J 2012;45:363-71. (Crossref)

8. Eliot C, Hatton JF, Stewart GP et al. The effect of the irrigant QMix on removal of canal wall smear layer: an ex vivo study. Odontology 2014;102:232-40. (Crossref)

9. Haapasalo M, Shen Y, Qian W, Gao Y. Irrigation in endodontics. Dent Clin North Am 2010;54:291-312. (Crossref) 
10. Wang Z, Shen Y, Ma J, Haapasalo M. The effect of detergents on the antibacterial activity of disinfecting solutions in dentin. J Endod 2012;38:948-53. (Crossref)

11. Bui TB, Baumgartner JC, Mitchell JC. Evaluation of the interaction between sodium hypochlorite and chlorhexidine gluconate and its effect on root dentin. J Endod 2008;34:1815. (Crossref)

12. Van Noort R. Introduction to dental materials. 2nd Ed. London, England: Mosby Int. Pub. Ltd. 2003:96-123.

13. Kakaboura A, Fragouli M, Rahiotis C, Silikas N. Evaluation of surface characteristics of dental composites using profilometry, scanning electron, atomic force microscopy and gloss-meter. J. Mater. Sci. Mater. Med.2007;18(1):155-63. (Crossref)

14. Jefferies SR. The art and science of abrasive finishing and polishing in restorative dentistry. Dent. Clin. North Am.1998;42(4):613-27.

15. Whitehead SA, Shearer AC, Watts DC, Wilson NH. Comparison of methods for measuring surface roughness of ceramic. J. Oral Rehabil.1995;22(6):421-7. (Crossref)

16. Heiling I, Steinberg D, Kenig $S$, et al. Efficacy of a substainedrelease device containing chlorhexidine and $\mathrm{CAOH}$ in preventing secondary infection dentinal of tubules. Int endod $\mathrm{J}$ 1992;25:20-4. (Crossref)

17. Erickson RL. Surface interactions of dentin adhesive materials. Operative Dentistry 1992;5:81-94.

18. Buzoglu HD, Calt S, Gumusderelioglu M. Evaluation of thesurface free energy on root canal dentine walls treated with chelating agents and $\mathrm{NaOCl}$. Int Endod J 2007;40:18-24. (Crossref)

19. Pashley D, Okabe A, Parham P. The relationship between dentin microhardness and tubule density. Endod Dent Traumatol 1985;1:176-9. (Crossref)

20. Lewinstein I, Hirschfeld Z, Stabholz Rotstein I. Effect of hydrogen peroxide and sodium perborate on the microhardness of human enamel and dentin. J Endod 1994;20:61-3. (Crossref)

21. Oliveira LD, Carvalho CA, Nunes W, Valera MC, Camargo CH, Jorge AO. Effects of chlorhexidine and sodium hypochlorite on the microhardness of root canal dentin. Oral Surg Oral Med Oral Pathol Oral Radiol Endod 2007;104:125-8. (Crossref)

22. Arend J, Ten Bosch JJ. Demineralization and remineralization evaluation techniques. J Dent Res 1992;71:924-8. (Crossref)

23. Sayin TC, Serper A, Cehreli ZC, Kalayci S. Calcium loss from root canal dentin following EDTA, EGTA, EDTAC, and tetracycline- $\mathrm{HCl}$ treatment with or without subsequent $\mathrm{NaOCl}$ irrigation. J Endod 2007;33:581-4. (Crossref)

24. Zhang K, Kim YK, Cadenaro M, et al. Effects of different exposure times and concentrations of sodium hypochlorite/ ethylenediaminetetraacetic acid on the structural integrity of mineralized dentin. J Endod 2010;36:105-9. (Crossref)

25. Fusayama T. Two layers of carious dentine. In: New concepts in operative dentistry. Chicago, IL: Quintessence Pub, 1980:18 -9 .

26. Panighi $M, G$ 'Sell $C$. Influence of calcium concentration on the dentin wettability by an adhesive. J Biomed Mater Res 1992;26:1081-9. (Crossref)

27. Akcay I, Sen BH. The effect of surfactant addition to EDTA on microhardness of root dentin. J Endod 2012;38:704-7. (Crossref)
28. Ari H, Erdemir A, Belli S. Evaluation of the effect of endodontic irrigation solutions on the microhardness and the roughness of root canal dentin. J Endod 2004;30(11):792-5. (Crossref)

29. Oliveira LD, Carvalho CA, Nunes W, Valera MC, Camargo $\mathrm{CH}$, Jorge AO. Effects of chlorhexidine and sodium hypochlorite on the microhardness of root canal dentin. Oral Surg Oral Med Oral Pathol Oral Radiol Endod 2007;104:125-8. (Crossref)

30. Slutzky-Goldberg I, Maree M, Liberman R, Heling I. Effect of sodium hypochloride on dentin microhardness. J Endod 2004;30:880-2. (Crossref)

31. Aslantaș EE, Doğan Buzoğlu H, Altundasar E, Serper A. Effect of EDTA, Sodium Hypochlorite, and Chlorhexidine Gluconate with or without Surface Modifiers on Dentin Microhardness. J Endod 2014;40:876-9. (Crossref)

32. Erdemir A, Ari H, Gungunes H, Belli S. Effect of medicaments for root canal treatment on bonding to root canal dentin. J Endod 2004;30:113-6. (Crossref)

33. Aranda-Garcia AJ, Kuga MC, Chavez-Andrade GM, et al. Effect of final irrigation protocols on microhardness and erosion of root canal dentin. Microsc Res Tech 2013;76:1079-83. (Crossref)

34. Aranda-Garcia AJ, Kuga MC, Vitorino KR, et al. Effect of the root canal final rinse protocols on the debris and smear layer removal and on the push-out strength of an epoxy-based sealer. Microsc Res Tech 2013;76:533-7. (Crossref)

35. Morgental RD, Singh A, Sappal H, Kopper PMP, Vier-Pelisser FV, Peters OA. Dentin inhibits the antibacterial effect of new and conventional endodontic irrigants. J Endod 2013;39:406-10. (Crossref)

36. Gordon TM, Damato D, Christner P. Solvent effect of various dilutions of sodium hypochlorite on vital and necrotic tissue. $J$ Endod 1981;7:466-9. (Crossref)

37. Hu X, Ling J, Gao Y. Effects of irrigation solutions on dentin wettability and roughness. J Endod 2010;63:1064-7. (Crossref)

38. Hu X, Peng Y, Sum C-P, Ling J. Effects of Concentrations and Exposure Times of Sodium Hypochlorite on Dentin Deproteination: Attenuated Total Reflection Fourier Transform Infrared Spectroscopy Study. J Endod 2010;36: 2008-11. (Crossref)

39. Cruz-Filho AM, Paula EA, Pecora JD, et al. Effect of different EGTA concentrations on dentin microhardness. Braz Dent J 2002;13:188-90. (Crossref)

40. Quirynen $M$, Bollen $C M$. The influence of surface roughness and surface-free energy on supra- and subgingival plaque formation in man: a review of the literature. J Clin Periodontol 1995;22:114. (Crossref)

41. Kokkas AB, Boutsioukis $A C H$, Vassiliadis LP, Stavrianos CK. The influence of the smear layer on dentinal tubule penetration depth by three different root canal sealers: an in vitro study. $J$ Endod 2004;30:100-2. (Crossref)

42. Vilanova WV, Carvalho-Junior JR, Alfredo E, Sousa-Neto MD, Silva- Sousa YT. Effect of intracanal irrigants on the bond strength of epoxy resin-based and methacrylate resin-based sealers to root canal walls. Int Endod J 2012;45:42-8. (Crossref)

43. Estrela C, Estrela CR, Barbin EL, Spano JC, Marchesan MA, Pecora JD. Mechanism of action of sodium hypochlorite. Braz Dent J 2002;13:113-7. (Crossref) 